\title{
Accuracy of the 15-item Geriatric Depression Scale (GDS-15) in a community-dwelling oldest-old sample: the Pietà Study
}

\author{
Acurácia da versão de 15 itens da Escala de Depressão Geriátrica (GDS-15) em \\ uma amostra de idosos muito-idosos residentes na comunidade: Estudo Pietà
}

\begin{abstract}
Filipi Leles da Costa Dias, ${ }^{1,2}$ Antônio Lúcio Teixeira, ${ }^{1,2}$ Henrique Cerqueira Guimarães, ${ }^{2}$ Maira Tonidandel Barbosa, ${ }^{1,2}$
\end{abstract}
Elisa de Paula França Resende, ${ }^{2}$ Rogério Gomes Beato, ${ }^{2}$ Karoline Carvalho Carmona, ${ }^{1,2}$ Paulo Caramelli ${ }^{1,2}$

\begin{abstract}
Introduction: Late-life depression (LLD) is common, but remains underdiagnosed. Validated screening tools for use with the oldest-old in clinical practice are still lacking, particularly in developing countries.

Objectives: To evaluate the accuracy of a screening tool for LLD in a community-dwelling oldest-old sample.

Methods: We evaluated 457 community-dwelling elderly subjects, aged $\geq 75$ years and without dementia, with the Geriatric Depression Scale (GDS-15). Depression diagnosis was established according to DSM-IV criteria following a structured psychiatric interview with the Mini International Neuropsychiatric Interview (MINI).

Results: Fifty-two individuals (11.4\%) were diagnosed with major depression. The area under the receiver operating characteristic $(R O C)$ curve was $0.908(p<0.001)$. Using a cut-off score of $5 / 6$ (not depressed/depressed), 84 (18.4\%) subjects were considered depressed by the GDS-15 (kappa coefficient $=53.8 \%, p<0.001)$. The $4 / 5$ cut-off point achieved the best combination of sensitivity (86.5\%) and specificity $(82.7 \%)$ (Youden's index $=0.692$ ), with robust negative $(0.9802)$ and reasonable positive predictive values (0.3819).

Conclusion: GDS-15 showed good accuracy as a screening tool for major depression in this community-based sample of low-educated oldest-old individuals. Our findings support the use of the $4 / 5$ cut-off score, which showed the best diagnostic capacity.
\end{abstract}

Keywords: Depression, geriatric psychiatry, geriatric assessment.

\section{Resumo}

Introdução: A depressão geriátrica (DG) é um transtorno prevalente que permanece sendo subdiagnosticado. Ferramentas validadas para rastreio de DG em idosos muito idosos na prática clínica são necessárias, especialmente em países em desenvolvimento.

Objetivos: Avaliar a acurácia diagnóstica da Escala de Depressão Geriátrica (Geriatric Depression Scale, GDS-15) em uma população de idosos muito idosos residentes na comunidade.

Métodos: Foram avaliados, com a GDS-15, 457 indivíduos nãodemenciados, residentes na comunidade, com idade $\geq 75$ anos. $O$ diagnóstico definitivo de depressão maior foi realizado através da entrevista semiestruturada Mini International Neuropsychiatric Interview (MINI), de acordo com os critérios do DSM-IV.

Resultados: Cinquenta e dois indivíduos (11,4\%) foram diagnosticados com episódio depressivo maior. A área sob a curva receiver operating characteristic $(R O C)$ foi de $0,908(p<0,001)$. Utilizando-se o ponto de corte $5 / 6$ (não-deprimido/deprimido), $84(18,4 \%)$ indivíduos foram considerados deprimidos pela GDS15 (coeficiente de kappa $=53,8 \%, p<0,001$ ). O ponto de corte $4 / 5$ atingiu a melhor combinação entre sensibilidade $(86,5 \%)$ e especificidade $(82,7 \%)$ (índice de Youden $=0,692$ ), com valor preditivo negativo robusto $(0,9802)$ e razoável valor preditivo positivo $(0,3819)$.

Conclusão: A GDS-15 demonstrou boa acurácia para o rastreio de depressão maior nesta amostra de base populacional de idosos muito idosos com baixa escolaridade. Os resultados do presente estudo indicam que o ponto de corte 4/5 mostrou-se mais adequado para utilização nesta população.

Descritores: Depressão, psiquiatria geriátrica, avaliação geriátrica.

\footnotetext{
${ }^{1}$ Programa de Pós-Graduação em Ciências Aplicadas à Saúde do Adulto, Faculdade de Medicina, Universidade Federal de Minas Gerais (UFMG), Belo Horizonte, MG, Brazil. ${ }^{2}$ Grupo de Pesquisa em Neurologia Cognitiva e do Comportamento, Departamento de Clínica Médica, Faculdade de Medicina, UFMG, Belo Horizonte, MG, Brazil.

The Pietà Study, from which this paper derives, took place in Caeté, MG, Brazil, and is partially supported by Conselho Nacional de Desenvolvimento Científico e Tecnológico (CNPq) and Fundação de Amparo à Pesquisa de Minas Gerais (FAPEMIG).

The present work was presented in poster format at the 2016 World Congress of Brain, Behavior and Emotions, in Buenos Aires, Argentina, and is part of the first author's ongoing doctoral thesis.

Submitted Apr 05 2017, accepted for publication May 192017.

Suggested citation: Dias FL, Teixeira AL, Guimarães HC, Barbosa MT, Resende EP, Beato RG, et al. Accuracy of the 15-item Geriatric Depression Scale (GDS-15) in a community-dwelling oldest-old sample: the Pietà Study. Trends Psychiatry Psychother. 2017;39(4):276-279. http://dx.doi.org/10.1590/2237-6089-2017-0046
} 


\section{Introduction}

In the last decades, the world has been going through important demographic changes with a growing elderly population. ${ }^{1}$ This phenomenon, which is even more substantial in developing countries, creates a crowd of oldest-old people prone to develop neuropsychiatric disorders.

Late-life depression (LLD) is the most common psychiatric disorder in the elderly. Prevalence rates differ depending on study setting, population, diagnostic instrument and age range. A systematic review found prevalence rates of LLD for individuals aged 75 years and over between $4.6 \%$ and $9.3 \% .^{2}$ LLD has been associated with increased morbidity, use of health services and mortality rates, ${ }^{3}$ making this disorder an important public health issue.

Despite its pivotal public health relevance, LLD remains largely underdiagnosed and undertreated. Hence, it is of utmost importance that elderly individuals be actively screened for LLD. In order to do that, an instrument specifically validated for use in the oldestold population is necessary.

The 15-item version of the Geriatric Depression Scale (GDS-15) ${ }^{4}$ is a time-constrained intervieweradministered scale with good psychometric properties and wide acceptance in the scientific community. It has been translated and validated for the Brazilian elderly population, ${ }^{5}$ but to date, no study has been conducted specifically with individuals aged $75+$ years.

The objective of this study was to evaluate the accuracy of the GDS-15 for diagnosing LLD in a community-dwelling oldest-old sample.

\section{Methods}

\section{Study design and targeted population}

This cross-sectional analysis is part of the Pietà Study, an epidemiological investigation on brain aging, conducted in Caeté, state of Minas Gerais, Brazil. ${ }^{6}$ In 2007, a year before data collection, 1,251 individuals aged $75+$ years were living in the city and were invited to participate in the study. Community agents from the family health program and municipal health department were contacted, and announcements were aired on local radio stations and printed in newspapers. The research team visited the two existing institutions in Caeté to identify eligible institutionalized elderly individuals. A total of 639 individuals $(51.1 \%$ of the target population within this age group) agreed to participate in the study and were subjected to a comprehensive medical, neurological and psychiatric evaluation.

\section{Instruments}

All 639 individuals were interviewed by either a boardcertified psychiatrist, neurologist or geriatrician, with at least 3 years of experience in neurological and psychiatric evaluation of elderly individuals, using the GDS-154,5 and the Mini International Neuropsychiatric Interview (MINI). ${ }^{7}$ Major depression was diagnosed based on criteria from the Diagnostic and Statistical Manual of Mental Disorders, 4th edition (DSM-IV), according to MINI results. In order to establish the diagnosis of dementia, individuals went through a cognitive evaluation comprising the Mini-Mental State Examination (MMSE), ${ }^{8}$ Brief Cognitive Battery (BCB) ${ }^{9-11}$ Functional Assessment Staging ${ }^{12}$ and Pfeffer's Functional Activities Questionnaire (FAQ). ${ }^{13}$

\section{Exclusion criteria}

Subjects who refused or could not sign the informed consent form and had no legally accepted representatives were not included. Also, individuals with severe sensory impairment that precluded appropriate understanding of the questionnaires were excluded. We further excluded individuals who were diagnosed as having dementia according to DSM-IV criteria, after adjudication of cognitive status.

\section{Ethical considerations}

The study was approved by the ethics committee of Universidade Federal de Minas Gerais, and all participants or their legally acceptable representatives signed the written informed consent form.

\section{Statistical analysis}

All statistical analyses were conducted using the Statistical Package for the Social Sciences (SPSS) version 20. Kappa coefficient was calculated to evaluate the level of agreement between GDS-15 and MINI results. A receiver operating characteristic ( $R O C)$ curve was used to calculate sensitivity and specificity for different GDS-15 cut-off scores. $p$-values $<0.05$ were considered as statistically significant.

\section{Results}

Of 639 individuals, 174 were diagnosed as having dementia, and 8 subjects had missing data and were thus excluded from the analysis. Within the final sample ( $n=457), 52$ subjects $(11.4 \%)$ were diagnosed by the MINI as having major depression; of these, $77.8 \%$ were female, with $80.7 \pm 4.6$ years of age and $3.9 \pm 3.4$ years of schooling.

Using the previously established cut-off score of $5 / 6$ (not depressed/depressed), ${ }^{5} 84$ (18.4\%) subjects 
(69.1\% female, $81.1 \pm 4.9$ years of age and $3.6 \pm 3.1$ years of schooling) were considered depressed by the GDS-15. The kappa agreement coefficient between GDS-15 and MINI was 53.8\% $(p<0.001)$ - low, but statistically significant. This finding is expected if we take into account that both a screening tool and a goldstandard instrument were used.

The area under the ROC curve was $0.908(p<0.001)$, which denotes very good diagnostic accuracy of the GDS-15 for individuals aged $\geq 75$ years. Using Youden's index, the $4 / 5$ cut-off score achieved the best combination of sensitivity and specificity (86.5 and $82.7 \%$, respectively; Youden's index $=0.692$ ) and presented a negative predictive value as strong as the lower cut-off points $(0.9802)$, with a more powerful positive predictive value $(0.3819)$ (Table 1$)$.

\section{Discussion}

Our findings reinforce the use of the GDS-15 as a suitable instrument for screening depression in this low-educated Brazilian population of oldest-old individuals, and suggest a lower cut-off score as more appropriate.

The cut-off score that had the best performance in our study is different from that proposed (5/6) in the scale validation study conducted in $\mathrm{Brazil}^{5}$ and from other cut-offs already used. ${ }^{14}$ It is possible that this divergence stems from the very low levels of schooling and higher mean age of the population studied in the present investigation, compared to the aforementioned studies. Conversely, our findings are in agreement with those reported by Marc et al., who proposed the 4/5 cut-off score when studying an elderly homebound population. ${ }^{15}$ Hence, for low-educated individuals in latest life, a lower threshold for a positive screening in the GDS-15 seems more appropriate.

Considering the low level of agreement with the semi-structured psychiatric interview in our study, the GDS-15 should be used only for screening purposes, or, when applied in prevalence studies, should imply a diagnosis of clinically significant depressive symptoms ${ }^{16}$ rather than of major depressive episode as seen in some studies. ${ }^{2}$

Even though the studied sample was representative of the oldest-old city population, one of the limitations of our work resides on the relatively low response rate to participate in the study. Conversely, the main strength is that diagnosis of LLD was made via semi-structured interviews performed by experienced physicians. Furthermore, dementia diagnosis, as an exclusion criterion, was established after the performance of comprehensive cognitive and functional evaluations and discussions among study clinicians/researchers until consensus was reached.

In conclusion, the GDS-15 showed good accuracy as a screening tool for major depression in oldest-old low-educated Brazilian individuals. The 4/5 cut-off score showed the best performance, balancing the test's sensitivity and specificity, with good negative and positive predictive values.

Table 1 - Diagnostic properties for different cut-off points of the 15-item Geriatric Depression Scale

\begin{tabular}{|c|c|c|c|c|c|}
\hline Not depressed/Depressed & Sensitivity & Specificity & Youden's index* & PPV $^{+}$ & $\mathbf{N P V}^{+}$ \\
\hline $1 / 2$ & 0.981 & 0.348 & 0.329 & 0.1568 & 0.9932 \\
\hline $2 / 3$ & 0.942 & 0.568 & 0.51 & 0.2122 & 0.9875 \\
\hline $3 / 4$ & 0.942 & 0.733 & 0.675 & 0.3036 & 0.9903 \\
\hline $4 / 5$ & 0.865 & 0.827 & 0.692 & 0.3819 & 0.9802 \\
\hline $5 / 6$ & 0.788 & 0.894 & 0.682 & 0.4788 & 0.9715 \\
\hline $6 / 7$ & 0.692 & 0.919 & 0.611 & 0.5135 & 0.9602 \\
\hline $7 / 8$ & 0.538 & 0.948 & 0.486 & 0.5611 & 0.9431 \\
\hline $8 / 9$ & 0.442 & 0.968 & 0.41 & 0.6306 & 0.9334 \\
\hline $9 / 10$ & 0.288 & 0.98 & 0.268 & 0.6402 & 0.9176 \\
\hline $10 / 11$ & 0.192 & 0.995 & 0.187 & 0.8259 & 0.9087 \\
\hline $11 / 12$ & 0.154 & 0.998 & 0.152 & 0.9049 & 0.9051 \\
\hline $12 / 13$ & 0.115 & 1 & 0.115 & 1 & 0.90 \\
\hline $13 / 14$ & 0.096 & 1 & 0.096 & 1 & 0.8994 \\
\hline $14 / 15$ & 0.038 & 1 & 0.038 & 1 & 0.8937 \\
\hline
\end{tabular}

NPV = negative predictive value; PPV = positive predictive value.

* Youden's index = sensitivity + specificity -1.

+ Statistics calculated considering a mean prevalence of $11 \%$ in the study population. 


\section{Acknowledgments}

The Pietà Study is partially supported by Conselho Nacional de Desenvolvimento Científico e Tecnológico (CNPq) and Fundação de Amparo à Pesquisa de Minas Gerais (FAPEMIG). We acknowledge the partnership from Instituto Hermes Pardini and Laboratório Geraldo Lustosa. We greatly thank Maria Ângela Dutra Ornellas for the local coordination of the operational arrangements. We are deeply grateful to the City Hall, the Municipal Health Department and the Retired and Pensioner Pavilion from Caeté, state of Minas Gerais, for their continuous support to the Pietà Study, and also to all elderly participants and their families for the generous collaboration and engagement in the research project.

Antonio Lucio Teixeira and Paulo Caramelli receive support from CNPq (Research Productivity grant).

\section{Disclosure}

No conflicts of interest declared concerning the publication of this article.

\section{References}

1. United Nations, Department of Economic and Social Affairs, Population Division. World population ageing 2015 - Highlights. New York: United Nations; 2015.

2. Luppa M, Sikorski C, Luck T, Ehreke L, Konnopka A, Wiese B, et al. Age- and gender-specific prevalence of depression in latest-life-systematic review and meta-analysis. J Affect Disord. 2012;136:212-21.

3. Wilkins $\mathrm{CH}$, Mathews J, Sheline YI. Late life depression with cognitive impairment: evaluation and treatment. Clin Interv Aging. 2009;4:51-7.
4. Yesavage JA, Brink $T L$, Rose $T L$, Lum $O$, Huang $V$, Adey $M$, et al. Development and validation of a geriatric depression screening scale: a preliminary report. J Psychiatr Res. 1982;17:37-49.

5. Almeida OP, Almeida SA. Reliability of the Brazilian version of the abbreviated form of Geriatric Depression Scale (GDS) short form. Arq Neuropsiquiatr. 1999;57:421-6.

6. Caramelli P, Barbosa MT, Sakurai E, Dos Santos EL, Beato RG, Machado JC, et al. The Pieta Study: epidemiological investigation on successful brain aging in Caete (MG), Brazil. Methods and baseline cohort characteristics. Arq Neuropsiquiatr. 2011;69:57984.

7. Amorim P. Mini International Neuropsychiatric Interview (MINI): validation of a short structured diagnostic psychiatric interview. Rev Bras Psiquiatr. 2000;22:106-15.

8. Folstein MF, Folstein SE, McHugh PR. "Mini-mental state". A practical method for grading the cognitive state of patients for the clinician. J Psychiatr Res. 1975;12:189-98.

9. Nitrini $R$, Lefevre $B H$, Mathias SC, Caramelli $P$, Carrilho PE, Sauaia N, et al. Neuropsychological tests of simple application for diagnosing dementia. Arq Neuropsiquiatr. 1994;52:457-65.

10. Castro $S$, Damin AE, Porto SC, Caramelli $P$, Nitirini R. The abbreviated form of the Brief Cognitive Battery in the diagnosis of dementia in Alzheimer's disease. Dement Neuropsychol. 2009;3:327-31.

11. Nitrini $R$, Caramelli $P$, Herrera Junior $E$, Porto $C S$, CharchatFichman $\mathrm{H}$, Carthery MT, et al. Performance of illiterate and literate nondemented elderly subjects in two tests of long-term memory. ] Int Neuropsychol Soc. 2004;10:634-8.

12. Sclan SG, Reisberg B. Functional assessment staging (FAST) in Alzheimer's disease: reliability, validity, and ordinality. Int Psychogeriatr. 1992;4 Suppl 1:55-69.

13. Pfeffer RI, Kurosaki $\Pi$, Harrah $\mathrm{CH}$, Jr., Chance JM, Filos $\mathrm{S}$. Measurement of functional activities in older adults in the community. J Gerontol. 1982;37:323-9.

14. de Craen AJ, Heeren TJ, Gussekloo J. Accuracy of the 15-item Geriatric Depression Scale (GDS-15) in a community sample of the oldest old. Int J Geriatr Psychiatry. 2003;18:63-6.

15. Marc LG, Raue PJ, Bruce ML. Screening performance of the 15item Geriatric Depression Scale in a diverse elderly home care population. Am J Geriatr Psychiatry. 2008;16:914-21.

16. Beekman AT, Copeland JR, Prince MJ. Review of community prevalence of depression in later life. $\mathrm{Br} J$ Psychiatry. 1999; 174:307-11.

\section{Correspondence:}

Paulo Caramelli

Av. Prof. Alfredo Balena, 190, Sala 246

30130-100 - Belo Horizonte, MG - Brazil

Tel./Fax: +55-31-3409.9746

E-mail: caramelli@ufmg.br 